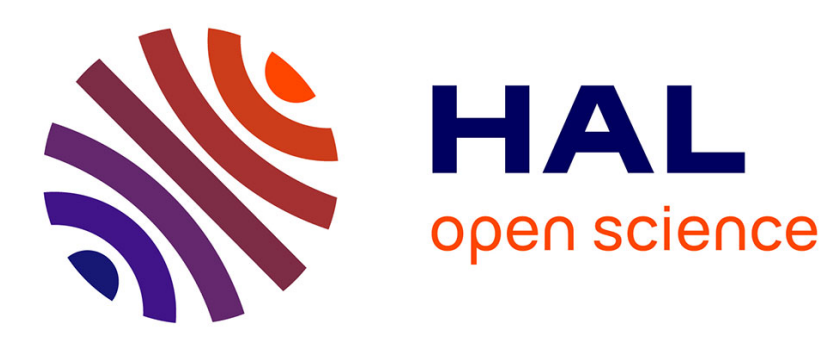

\title{
US Food and Drug Administration approval of esketamine and brexanolone
}

Ioana A Cristea, Florian Naudet

\section{To cite this version:}

Ioana A Cristea, Florian Naudet. US Food and Drug Administration approval of esketamine and brexanolone. The Lancet. Psychiatry, 2019, 6 (12), pp.975-977. 10.1016/S2215-0366(19)30292-5 . hal-02363651

\section{HAL Id: hal-02363651 https://hal-univ-rennes1.archives-ouvertes.fr/hal-02363651}

Submitted on 18 Feb 2020

HAL is a multi-disciplinary open access archive for the deposit and dissemination of scientific research documents, whether they are published or not. The documents may come from teaching and research institutions in France or abroad, or from public or private research centers.
L'archive ouverte pluridisciplinaire HAL, est destinée au dépôt et à la diffusion de documents scientifiques de niveau recherche, publiés ou non, émanant des établissements d'enseignement et de recherche français ou étrangers, des laboratoires publics ou privés. 


\title{
US Food and Drug Administration approval of esketamine and brexanolone
}

\author{
Ioana A. Cristea, $\mathrm{PhD}^{\mathrm{a}, \mathrm{b}}$, Florian Naudet, $\mathrm{MD}, \mathrm{PhD}^{\mathrm{c}}$
}

${ }^{a}$ Department of Clinical Psychology and Psychotherapy, Babes-Bolyai University, Republicii 37

Street, Cluj-Napoca, Romania, e-mail: ioanacristea@psychology.ro

${ }^{\mathrm{b}}$ Meta-Research Innovation Center at Stanford (METRICS), Stanford University, Stanford, CA 94305, California, USA

${ }^{\mathrm{c}}$ University Rennes, CHU Rennes, Inserm, CIC 1414 [(Centre d'Investigation Clinique de Rennes)], F- 35000 Rennes, France, e-mail : floriannaudet@gmail.com

Correspondence concerning this article should be addressed to Ioana A. Cristea, Department of Clinical Psychology and Psychotherapy, Babes-Bolyai University, Republicii 37 Street, 400015 Cluj-Napoca, Romania, tel/fax: +40264434141, e-mail: ioanacristea@psychology.ro

Word count: 895 and one table 
In March 2019, The US Food and Drug Administration (FDA) approved two new antidepressants - esketamine for treatment-resistant depression (TRD) ${ }^{1}$ and brexanolone for postpartum depression (PPD) $)^{2}$. Both had "Breakthrough" designation, an expedited review process for drugs "intended to treat a serious condition and preliminary clinical evidence indicates that the drug may demonstrate substantial improvement over available therapy on a clinically significant endpoint( $s)^{\prime 3}$. Though new interventions are welcome for these debilitating disorders, we are concerned these approvals share common critical features, and could further lower the bar in the evaluation of treatments for mental disorders.

Both drugs were approved for medically supervised administration only, with a boxed warning due to serious adverse effects (Table). These include sedation, dissociation and suicidal ideation and behaviors for esketamine ${ }^{1}$ and loss of consciousness and syncope for brexanolone ${ }^{2}$. Moreover, although the risk of misuse for esketamine is unknown, the abuse potential of the related molecule, ketamine, is well-documented, albeit less common than for other frequently abused hallucinogens like ecstasy or $\mathrm{LSD}^{1}$.

Brexanolone's administration through a continuous 60 hours intravenous drip ${ }^{2}$ and the requirement of a minimum inpatient stay of $21 / 2$ days represent considerable hindrances for mothers, due to the danger of disrupting breastfeeding, caregiving and early attachment. Many healthcare facilities do not have psychiatric mother-baby units, making hospitalization equivalent to mother-infant separation. Patients for whom these conditions are unacceptable might grapple with anxiety and guilt over the loss of a potential cure. Had it not been for the treatment administration, few PPD patients in the pivotal trials would have required inpatient care ${ }^{4}$.

Effective treatments are often accompanied by serious adverse effects, which many patients are willing to withstand as trade-off for expected benefits. Still, a balance needs to be 
struck between benefits and harms. For esketamine and brexanolone, the degree of medicalization and risk of serious adverse effects need to be counterbalanced by strong efficacy results. Yet results from the pivotal trials were modest at best (Table). For esketamine ${ }^{1}$, one short-term trial demonstrated significant benefits over placebo, while two others found no difference. A dose-response relationship suggested in a phase 2 study could not be confirmed ${ }^{1}$. In a first for the FDA's Division of Psychiatry Products, a maintenance trial showing esketamine's continued antidepressant response counted towards the requirement of two positive trials ${ }^{1}$. Furthermore, for one trial, the FDA reviewer described data integrity issues ${ }^{1}$, such as an "unusual response curve shift" at posttest, "discrepancies between the locked datasets" and "reported protocol violations" (p.32). No efficacy results were reported for the 24-week follow-up of the short-term trials ${ }^{1}$. Brexanolone showed a large effect compared to placebo at 60 hours postinfusion $^{2}$ in a phase 2 trial. Two short-term phase 3 trials showed considerably smaller effects at the same timepoint, and, in one, differences had largely dissipated at 30 days (the longest followup). ${ }^{2}$ Perhaps as a consequence of the drugs' rapid onset of action ${ }^{1,4}$, the timing of outcome assessment drifted to shorter durations, ranging from hours (60 hours in the pivotal brexanolone trials $^{2}$ ) to days (28 days in the esketamine trials ${ }^{1}$ ), even for follow-up (e.g., 30 days for brexanolone trials) $)^{2}$.

Furthermore, we are wary of the notion that multifactorial, protracted or poorly defined conditions like TRD or PPD could be both rapidly and enduringly resolved. Treatment-resistant depression is marred by diagnostic ambiguity regarding the nature and number of failed treatments, as well as by significant heterogeneity ${ }^{5}$. The concept itself misleadingly implies developing sensitivity to a highly effective treatment (e.g., "antibiotic resistance"), though most antidepressants show modest benefits over placebo ${ }^{6}$ and thus may not be effective to begin with 
for many patients. Beyond semantics, TRD is a chronic and disabling form of depression ${ }^{5}$, as is PPD, which can result in negative long-term effects for both woman and child ${ }^{7}$. Moreover, PPD was linked to a constellation of risk factors, including history of physical and sexual abuse, lack of social and financial support, or medical complications like gestational diabetes ${ }^{7}$.

Therefore, for both disorders, benefits measured on a symptom scale at 60 hours or 28 days can only be a surrogate of long-term functional outcomes. For esketamine, longer-term effects were assessed in a maintenance $\operatorname{study}^{1}$, a design long criticized for inflating true treatment effects $^{8}$. In this 500-days study, esketamine was superior to placebo for time to relapse in stable remitters (Table). Yet most of the drug-placebo separation occurred early (2-4 weeks postrandomization), leading the FDA to question whether "functional unblinding" partially impacted results ${ }^{1}$.

Both drugs were compared to placebo and not the relevant "standard of care". For new treatments, particularly those with risk of serious harms, head-to-head trials against existent treatments are crucial. Superiority on patient-relevant outcomes - symptoms, but also quality of life and functioning - needs to be shown to justify widespread use. For example, psychological interventions, notably cognitive behavioral therapy and interpersonal therapy, are effective for both treating 9 and preventing $\mathrm{PPD}^{7}$, with benefits that persist at 6-months follow-up ${ }^{9}$. Psychotherapies showed moderate effects for chronically depressed patients ${ }^{10}$, several of whom would have presumably met at least one TRD definition ${ }^{5}$. Though more invasive, physical therapies, such as electroconvulsive therapy, also showed effectiveness for TRD ${ }^{11}$.

Since 2012, the FDA approved approximately 50 therapeutics with Breakthrough designation, most commonly for cancer ${ }^{12}$. The designation is frequently disconnected from the low-quality evidence supporting subsequent approvals ${ }^{12}$. We fear that the arguably already low 
bar for antidepressants, where some previously approved drugs had similar numbers of failed and positive trials ${ }^{13}$, will be lowered further. The FDA should hold future antidepressants to higher evidentiary standards before granting approval and the European Medicines Agency should carefully consider whether the existing evidence for brexanolone and esketamine is sufficient to warrant approval.

\section{Authors' contributions}

IAC and FN conceived, drafted and revised the manuscript.

\section{Declaration of interest}

IAC and $\mathrm{FN}$ have no conflicts of interest to disclose. 


\section{References:}

1. FDA. Briefing Information for the February 12, 2019 Joint Meeting of the Psychopharmacologic Drugs Advisory Committee (PDAC) and the Drug Safety and Risk Management Advisory Committee (DSaRM). In: Services HaH, editor.: Food and Drug Administration; 2019.

2. FDA. Briefing Information for the November 2, 2018 Joint Meeting of the Psychopharmacologic Drugs Advisory Committee (PDAC) and the Drug Safety and Risk Management Advisory Committee (DSaRM). In: Services HaH, editor.: Food and Drug Administration; 2019.

3. Administration USFD. Breakthrough Therapy. 01/04/2018.

https://www.fda.gov/patients/fast-track-breakthrough-therapy-accelerated-approval-priorityreview/breakthrough-therapy (accessed 06/15/2019.

4. Meltzer-Brody S, Colquhoun H, Riesenberg R, et al. Brexanolone injection in postpartum depression: two multicentre, double-blind, randomised, placebo-controlled, phase 3 trials. The Lancet 2018; 392(10152): 1058-70.

5. Conway CR, George MS, Sackeim HA. Toward an Evidence-Based, Operational Definition of Treatment-Resistant Depression: When Enough Is Enough. JAMA Psychiatry 2017; 74(1): 910.

6. Cipriani A, Furukawa TA, Salanti G, et al. Comparative efficacy and acceptability of 21 antidepressant drugs for the acute treatment of adults with major depressive disorder: a systematic review and network meta-analysis. The Lancet 2018; 391(10128): 1357-66.

7. Curry SJ, Krist AH, Owens DK, et al. Interventions to Prevent Perinatal Depression: US Preventive Services Task Force Recommendation Statement. Jama 2019; 321(6): 580-7.

8. Kopec JA, Abrahamowicz M, Esdaile JM. Randomized discontinuation trials: utility and efficiency. Journal of clinical epidemiology 1993; 46(9): 959-71.

9. Stephens S, Ford E, Paudyal P, Smith H. Effectiveness of Psychological Interventions for Postnatal Depression in Primary Care: A Meta-Analysis. Annals of family medicine 2016; 14(5): 463-72.

10. van Bronswijk S, Moopen N, Beijers L, Ruhe HG, Peeters F. Effectiveness of psychotherapy for treatment-resistant depression: a meta-analysis and meta-regression. Psychological Medicine 2019; 49(3): 366-79.

11. Milev RV, Giacobbe P, Kennedy SH, et al. Canadian Network for Mood and Anxiety Treatments (CANMAT) 2016 Clinical Guidelines for the Management of Adults with Major Depressive Disorder: Section 4. Neurostimulation Treatments. Canadian journal of psychiatry Revue canadienne de psychiatrie 2016; 61(9): 561-75.

12. Puthumana J, Wallach JD, Ross JS. Clinical Trial Evidence Supporting FDA Approval of Drugs Granted Breakthrough Therapy DesignationClinical Trial Evidence Supporting FDA Approval of Drugs Granted Breakthrough Therapy DesignationLetters. Jama 2018; 320(3): 3013.

13. Turner EH, Matthews AM, Linardatos E, Tell RA, Rosenthal R. Selective Publication of Antidepressant Trials and Its Influence on Apparent Efficacy. New England Journal of Medicine 2008; 358(3): 252-60. 
Table. Efficacy and safety data from pivotal trials ${ }^{1)}$

\begin{tabular}{|c|c|c|c|c|c|c|c|c|c|c|c|}
\hline \multirow[b]{2}{*}{ Study } & \multirow[b]{2}{*}{$\begin{array}{l}\text { NCT } \\
\text { (Clinicaltrials.gov) }\end{array}$} & \multirow[b]{2}{*}{ Trial type } & \multirow[b]{2}{*}{ Dose } & \multicolumn{4}{|c|}{ Primary outcome } & \multicolumn{3}{|c|}{ Longest follow-up } & \multirow{2}{*}{$\begin{array}{l}\text { Adverse events } \\
\text { (serious \& of } \\
\text { special interest) }\end{array}$} \\
\hline & & & & $\begin{array}{l}\text { Primary } \\
\text { outcome }\end{array}$ & $\begin{array}{l}\text { Time } \\
\text { frame }\end{array}$ & $\begin{array}{l}\text { Effect } \\
\text { size }^{2)}\end{array}$ & $\begin{array}{l}\mathrm{p}- \\
\text { value }\end{array}$ & $\begin{array}{l}\text { Time } \\
\text { frame }\end{array}$ & $\begin{array}{l}\text { Effect } \\
\text { size }^{2)}\end{array}$ & $\begin{array}{l}\mathrm{p}- \\
\text { value }\end{array}$ & \\
\hline \multicolumn{12}{|l|}{ Esketamine $^{4)}$} \\
\hline \multirow[t]{2}{*}{$\begin{array}{l}\text { TRD3001 } \\
\text { (TRANSFORM- } \\
1)^{5)}\end{array}$} & NCT02417064 & $\begin{array}{l}\text { Phase } 3 \\
\text { Short-term }\end{array}$ & $56 \mathrm{mg}$ & MADRS & $\begin{array}{l}4 \\
\text { weeks }\end{array}$ & $\begin{array}{l}-4.1(- \\
7.7 \text { to } \\
-0.5)\end{array}$ & $0.026^{6)}$ & $\begin{array}{l}24 \\
\text { weeks }\end{array}$ & $\begin{array}{l}\text { Only } \\
\text { safety } \\
\text { data }\end{array}$ & & \multirow{2}{*}{$\begin{array}{l}\text { Depression }(6 ; \\
2.6 \%) \\
\text { Suicidal ideation or } \\
\text { behavior }(4 ; 1.7 \%) \\
\text { Headache }(1 ; 0.4 \%) \\
\text { Severe sedation }(6 ; \\
2.6 \%) \\
\text { Dissociation }(151 ; \\
65 \%)\end{array}$} \\
\hline & & & $84 \mathrm{mg}$ & MADRS & $\begin{array}{l}4 \\
\text { weeks }\end{array}$ & $\begin{array}{l}-3.2(- \\
6.9 \text { to } \\
0.5)\end{array}$ & $0.088^{6}$ & $\begin{array}{l}24 \\
\text { weeks }\end{array}$ & $\begin{array}{l}\text { Only } \\
\text { safety } \\
\text { data }\end{array}$ & & \\
\hline $\begin{array}{l}\text { TRD3002 } \\
\text { (TRANSFORM- } \\
\text { 2) }\end{array}$ & NCT02418585 & $\begin{array}{l}\text { Phase } 3 \\
\text { Short term }\end{array}$ & $\begin{array}{l}56-84 \\
\mathrm{mg}\end{array}$ & MADRS & $\begin{array}{l}4 \\
\text { weeks }\end{array}$ & $\begin{array}{l}-4(- \\
7.3 \text { to } \\
-0.6)\end{array}$ & $0.020^{6)}$ & $\begin{array}{l}24 \\
\text { weeks }\end{array}$ & $\begin{array}{l}\text { Only } \\
\text { safety } \\
\text { data }\end{array}$ & & $\begin{array}{l}\text { Road traffic } \\
\text { accident/death ( } 1 \text {; } \\
0.9 \%) \\
\text { Cerebal hemorrhage } \\
(1 ; 0.9 \%) \\
\text { Severe sedation }(1 ; \\
0.9 \%) \\
\text { Dissociation }(80 ; \\
70 \%)\end{array}$ \\
\hline $\begin{array}{l}\text { TRD3005 } \\
\text { (TRANSFORM- } \\
\text { 3) }\end{array}$ & NCT02422186 & $\begin{array}{l}\text { Phase } 3 \\
\text { Short-term }\end{array}$ & $\begin{array}{l}28-84 \\
\mathrm{mg}\end{array}$ & MADRS & $\begin{array}{l}4 \\
\text { weeks }\end{array}$ & $\begin{array}{l}-3.6(- \\
7.2 \text { to } \\
0.07)\end{array}$ & $0.058^{6)}$ & $\begin{array}{l}24 \\
\text { weeks }\end{array}$ & $\begin{array}{l}\text { Only } \\
\text { safety } \\
\text { data }\end{array}$ & & $\begin{array}{l}\text { Depression }(1 ; \\
1.4 \%) \\
\text { Dizziness/Fall/Hip } \\
\text { fracture }(1 ; 1.4 \%) \\
\text { Suicidal ideation or } \\
\text { behavior }(1 ; 1.4 \%) \\
\text { Blood pressure } \\
\text { increased }(1 ; 1.4 \%) \\
\text { Dissociation }(57 ; \\
79 \%)\end{array}$ \\
\hline $\begin{array}{l}\text { TRD3002 } \\
\text { (SUSTAIN-1) }\end{array}$ & NCT02493868 & $\begin{array}{l}\text { Phase } 3 \\
\text { Maintenance }\end{array}$ & NR & $\begin{array}{l}\text { Time to } \\
\text { relapse in } \\
\text { stable } \\
\text { remitters }\end{array}$ & $\begin{array}{l}500 \\
\text { days }\end{array}$ & $\begin{array}{l}0.49 \\
(0.3 \text { to } \\
0.8)\end{array}$ & 0.003 & & & & \\
\hline
\end{tabular}




\begin{tabular}{|c|c|c|c|c|c|c|c|c|c|c|c|}
\hline \multicolumn{12}{|l|}{ Brexanolone } \\
\hline 547-PPD-202A & & Phase 2 & $\begin{array}{l}90 \\
\mu \mathrm{g} / \mathrm{kg} / \mathrm{h}\end{array}$ & HAM-D & $\begin{array}{l}60 \\
\text { hours }\end{array}$ & $\begin{array}{l}-12.2 \\
(-20.8 \\
\text { to }- \\
3.7)\end{array}$ & 0.008 & $\begin{array}{l}30 \\
\text { days }\end{array}$ & $\begin{array}{l}-11.9 \\
(-19.9 \\
\text { to }- \\
3.9)\end{array}$ & $0.004^{7)}$ & \multirow{4}{*}{$\begin{array}{l}\text { Loss of } \\
\text { consciousness, } \\
\text { syncope, pre- } \\
\text { syncope }(6 ; 4 \%) \\
\text { Suicidal ideation } \\
\text { and intentional } \\
\text { overdose }(1 ; 0.7 \%)\end{array}$} \\
\hline \multirow[t]{2}{*}{ 547-PPD-202B } & NCT02942004 & Phase 3 & $\begin{array}{l}60 \\
\mu \mathrm{g} / \mathrm{kg} / \mathrm{h}\end{array}$ & HAM-D & $\begin{array}{l}60 \\
\text { hours }\end{array}$ & $\begin{array}{l}-5.5(- \\
8.8 \text { to } \\
-2.2)\end{array}$ & 0.001 & $\begin{array}{l}30 \\
\text { days }\end{array}$ & $\begin{array}{l}-5.6(- \\
9.5 \text { to } \\
-1.8)\end{array}$ & 0.004 & \\
\hline & & & $\begin{array}{l}90 \\
\mu \mathrm{g} / \mathrm{kg} / \mathrm{h}\end{array}$ & & & $\begin{array}{l}-3.7(- \\
6.9 \text { to } \\
-0.5)\end{array}$ & 0.025 & $\begin{array}{l}30 \\
\text { days }\end{array}$ & $\begin{array}{l}-3.8(- \\
7.6 \text { to } \\
-0.0)\end{array}$ & 0.048 & \\
\hline 547-PPD-202C & NCT02942017 & Phase 3 & $\begin{array}{l}90 \\
\mu \mathrm{g} / \mathrm{kg} / \mathrm{h}\end{array}$ & HAM-D & $\begin{array}{l}60 \\
\text { hours }\end{array}$ & $\begin{array}{l}-2.5(- \\
4.5 \text { to } \\
-0.5)\end{array}$ & 0.016 & $\begin{array}{l}30 \\
\text { days }\end{array}$ & $\begin{array}{l}0.5(-2 \\
\text { to } 3.1)\end{array}$ & 0.67 & \\
\hline
\end{tabular}

Note. MADRS, Montgomery-Asberg Depression Rating Scale; HAM-D, Hamilton Depression Rating Scale

1) Data sources are FDA Briefing documents for Psychopharmacologic Drugs Advisory Committee (PDAC) and Drug Safety and Risk Management Advisory Committee Meeting (DSaRM) for NDA 211243 esketamine (https://www.fda.gov/downloads/AdvisoryCommittees/CommitteesMeetingMaterials/Drugs/PsychopharmacologicDrugsAdvisoryCommittee/UCM630970.pdf) and NDA 211371 brexanolone (https://www.fda.gov/downloads/AdvisoryCommittees/CommitteesMeetingMaterials/Drugs/PsychopharmacologicDrugsAdvisoryCommittee/UCM624643.pdf). All efficacy results were cross-checked against results posted on clinicaltrials.gov, with the exception of brexanolone study 547-PPD-202A, where no results were posted.

2) Versus placebo / Mean difference (least square) for scales / Hazard ratio for time-to-event outcomes

3) As described in the FDA DSaRM; Events; \% exposures in drug arm

4) Two Phase 2 trials (Study 2003/SYNAPSE and SUI2001) were not included due uncertainty as to whether they were considered pivotal for the FDA assessment.

5) As required by the study's hierarchical testing procedure the 56-mg dose should not have been formally analysed unless the 84-mg dose showed superiority to placebo

$\left.{ }^{6}\right) \mathrm{p}$-values were reported one-sided in the FDA PDAC for esketamine (i.e., compared to $\mathrm{p}=0.025$ ) and were transformed to two-sided (i.e., compared to $\mathrm{p}=0.05$ ) for comparability. When two-sided $\mathrm{p}$ values were given for the results posted on clinicaltrials.gov, these were used

7) p-value was not reported and calculated with the Altman-Bland (2011) method. 